\title{
Discovery Learning with Hierarchy Concept to Improve Analysis Ability and Study Achievement Hydrolysis Subject
}

\author{
Leny Yuliatun $^{1}{ }^{*}$, Mohammad Masykuri ${ }^{1}$, Budi Utami ${ }^{1}$ \\ ${ }^{1}$ Chemistry Education, Universitas Sebelas Maret. Jalan Ir. Sutami 36 A, Surakarta, 57126, Indonesia \\ * Correspondence Author. Email: tunnleny@gmail.com
}

Received: 4 May 2017; Revised: 6 September 2017; Accepted: 29 September 2017

\begin{abstract}
The aim of this research is to applied Discovery Learning (DL) by the support of hierarchy concept to improve analysis ability and chemistry study achievement in the Hydrolysis subject at eleventh-grade students of Science 1 of SMA N Karangpandan at the academic year of 2016/2017. This research is using Classroom Action Research which using two cycles. In each cycle has four steps of action, they are planning, implementing, observing, and reflecting. The research subject is the eleventh-grade students of science one which consists of 40 students. The data source is using teacher and students and the data were taken by interviewing, observing, documenting, testing, and using questionnaire. Data obtained processed in descriptive-qualitative data analysis with techniques that include the reduction of the data, the presentation of data, conclusion and withdrawal. data collection using test and non-test in the form, observation, interviews and document review. Based on the research shows that the achievement of analysis cycle I am from 52,5\% increase into $65 \%$ in the cycle II. Meanwhile, the rise in students' achievement in cognitive aspect increase from 57,5\% in cycle I to $75 \%$ in cycle II. Achievement in anaffective aspect in cycle I am $90 \%$ become $92,5 \%$ in cycle II. Therefore, there is the increase meant of students number in this aspect although in cycle I all of the indicator has been reached.
\end{abstract}

Keywords: discovery learning (DL), hydrolysis, analysis ability, classroom action research, study achievement.

How to Cite: Yuliatun, L., Masykuri, M., \& Utami, B. (2017). Discovery learning with hierarchy concept to improve analysis ability and study achievement hydrolysis subject. Jurnal Inovasi Pendidikan IPA, 3(2), 172179. doi:http://dx.doi.org/10.21831/jipi.v3i2.13919

Permalink/ DOI: http://dx.doi.org/10.21831/jipi.v3i2.13919

\section{INTRODUCTION}

Discovery learning important done by the teacher to make learning innovation in accordance with the curriculum in accordance with the scientific approach which demands students to be active in learning. In learning, there is a study process. According to Suprijono (2014: 3) study is a process to get knowledge. There are some aspects in getting knowledge, one of them is curriculum. The curriculum in Indonesia had undergone change several times, from 1994, KBK, KTSP, and the latest is curriculum 2013 (K13). Nowadays, the using of curriculum in every school is based on the school condition. Most of the school in Indonesia is using $\mathrm{K} 13$, but there are some schools still use KTSP, especially the school in the rural region. There are no significant differences between KTSP and K13.
Both of them is using Student Cenered Learning which make the students active in teaching and learning process. One of the school that still use KTSP is SMA N Karangpandan in Karanganyar regency. The application of $\mathrm{K} 13$ in SMA N Karangpandan has not been able to apply optimally in learning process, especially in chemistry learning. Based on the interview with teacher and students, teacher is using convential learning with using communicative learning which make students bored while study the chemistry. Furthermore, using conventional learning causes the students less active and just listen to explanation from the teacher, so the learning process become only one direction communication. So that, innovation in teaching and learning process is needed to make the students more active. One of the innovation is Discovery Learning. Discovery Learning has 
several advantages in the study, such as the students have self motivation to finish their work until they find their answers to their problems, be autonomous to solve their problems, and have skill to think critically because they should analyze and manage information (Baharuddin \& Wahyuni, 2010, pp.129-130).

It is also supported by an opinion that Discovery Learning strategy help to get study activity where students are studying to themselves and applying what they had known in the new situation to reach an effective learning easily (Abdelrahman \& Abdelrahman, 2014). The similar case is also conveyed that Discovery Learning assume that students take an activity and concept their basic knowledge (Swaak, Jong, \& Joolingen, 2014, p. 226).

Based on the interview with eleventh grade students of science 1, students want an innovation in teaching and learning process which make students more active and they are not bored in learning to find the concept. Students are not considered as a passive information user, but more active to get the content (Dabbagh \& Kitsantas, 2012). With having active behavior in learning process make students get and understand the point of the content, so they can reach the learning goal in finding concept in the learning subject.

Chemistry is the main lesson for science students in Senior High School. Three levels of learning chemistry, they are macroscopic, submacroscopic, and representational (symbolic) (Barke, Hazari, Yitbarek, 2009, pp. 27-28). Those three levels can be learnt in understanding chemistry concept. So that, if there is difficulty in a level will influence in another levers.

One of the subject in eleventh grade students of science in chemistry lesson at second semester is hydrolysis. In hydrolysis subject is needed more comprehension for the students of SMA N Karangpandan. It is appropriate with the completeness data of eleventh grade students of science class which found in Table 1.

Table 1. The Completeness of Hydrolysis Subject at Eleventh Grade Students of Science Class

\begin{tabular}{ccc}
\hline $\begin{array}{c}\text { Academic } \\
\text { Year }\end{array}$ & Class & $\begin{array}{c}\text { Completeness Score } \\
(\mathbf{\%})\end{array}$ \\
\hline $\mathbf{2 0 1 5 / 2 0 1 6}$ & XI Science 3 & 28,94 \\
& XI Science 4 & 26,31 \\
\hline
\end{tabular}

In previous years, students have a percentage completely on the hydrolysis subject is very low and has not yet reached $75 \%$ of the number of students who are finished in such subject. One of the classes which has difficulty in chemistry learning XI IPA 1 . It is proved from the result of study achevement in the final test of first semester at academic year of 2016/2017 at eleventh grade students of science 1 have the lowest average than the others classes.

Table 2. The Final Test Completeness of First Semester at eleventh grade students of science class.

\begin{tabular}{ccc}
\hline $\begin{array}{c}\text { Academic } \\
\text { Year }\end{array}$ & Class & $\begin{array}{c}\text { Completeness Score } \\
\text { (\%) }\end{array}$ \\
\hline $\mathbf{2 0 1 6 / 2 0 1 7}$ & XI Science 1 & 45 \\
& XI Science 2 & 50 \\
& XI Science 3 & 66,67 \\
\hline
\end{tabular}

It shows that eleventh grade students of science 1 need to improve the chemistry learning. Hydrolysis subject is still connected with the previous subject, acids and bases. Students can not fully know and analyze acid and base compound, especially in identifying belonged to strong acid, weak acid, stong base, or weak base. However, they have difficulty to determine the dalt formed.

In addition, students are still difficult to analyze the problems that are given through the material or question. Analyticalability is the ability to identify the real relationship of statements, concepts, and descriptions to express the conviction, experience, reason, information or opinions.Accordingto Facione, an indicator of the analysis thinking ability is interpreting information and ideas, identifying the similarities and differences between the information to solve problems, building hypotheses, and describing the related sentences or parts of a concept to make a decision (Facione, 2013). In XI IPA 1, analysis capability has not been used to its full potential by students, so there is much confusion and difficulty. This is appropriate with the test results of analysis ability that most students have the analytical skills of middle level. Analyzing is a method or process that involves the breakdown of the materials into small sections and determines the relationship between parts and the whole structure (Winarti, 2015). Based on the results of a test of analysis ability on precycle (pre-research), obtained by students who have high analysis capabilities of $33.33 \%$ so that it can be concluded that the analysis capability is still low. Based on the analysis of the results of the interviews and observation with the teachers and students, it can be noted that during the 


\section{Jurnal Inovasi Pendidikan IPA, 3 (2), 2017 - 174}

Leny Yuliatun, Mohammad Masykuri, Budi Utami

learning has never done innovation model and the use of media. It is possible to cause the low student value. Therefore it takes innovation model and the media in order to increase student value percent. The media that used in learning should be able to reduce student's misconceptions and assist students in finding a concept especially in determining the characteristic of the salt. One of them is using hierarchy concept. The use of hierarchy concept will improve the ability of students in analysis of hydrolysis. This is because the hierarchy concepts will guide students to analyze formulas and things to do so that the matter can be resolved properly. Hierarchy concept indicates decreasing the important information so at each step the students will note the appropriate content of each part of the hierarchy that will help understand and connect the subject to the material (Mustafa \& Murset, 2013). This is appropriate with the opinion of Novak and Gowin (2008: 36) hierarchy is a sequence of concept with the bottom of the draft more specific and less general than the higher concept which contains material that is mapped. This means that in the hierarchy concept has a level of general concept to specific concept that can be mapped in order. Salt hydrolysis subject is composed of a simple concept or basic to complex concepts that can form a hierarchy.

Based on those explanation, the researcher conclude that still needed a Classroom Action Research as one of learning innovation which make students more active, they are not bored, and broaden their knowledge to find out the concept by themselves. Therefore, to improve student analysis ability and achievement at hydrolysis subject in class XI IPA SMA N 1 Karangpandan year 2016/2017 lessons can be done through the application of Discovery Learning (DL) model with support hierarchy concepts.

\section{METHOD}

Classroom Action Research (CAR) consists of two cycles. In every cycle there are four stage of action, they are planning, implementing, observating, and reflecting. The research started at November 2016 for pre-research until March 2017. This research did in SMA N Karangpandan in Blora Street-Karangpandan, Karanganyar 57791.

Subject of this research is the eleventh grade students of science 1 of SMA N Karangpandanat academic year of 2016/2017 with consists of 40 students. The subject election is according to the problem which happen in the class of eleventh grade of science 1 when did the first research, interview, and analyze the documents. In the pre-cycle, the researcher did the interview with the chemistry teacher and the students of XI IPA 1. The result of the interview with the chemistry teacher is proved with the result of observation, interview with the students and pre-cycle test. Based on the result of precycle is got the analysis ability and study achievement in the XI IPA 1 is still low.

This research uses procedure with several stages, they are (1) preparation, (2) planning, (3) implementation the action, (4) observation, and (5) reflection. In the reflection, the action of the researcher and the teacher analyze and struggle to control the deficiency and weakness that happen from the result of action which is did. The success or the failure from the result of relection will be the basic to get the agreement when determine the next improvement action in cycle II.

\section{Data, Tools and Technique of Collecting Data}

The data that used in this research is qualitative and quantitative data. The data were taken from the result of the observation and interview in the pre-cycle, and also, researcher used the result of the final test of the students in the 1 st semester and the result of daily test of the students on the Hydrolisis subject in the previous year. Beside that, quantitative data was also formed into cognitive aspect test and affective on the 1 and 2 cycle.

The data source is used as the collection of the data and the digging of the matter and information in the eleventh grade of Science 1 including teacher, students, the result of the precycle test, the grade of final test of the students in the eleventh grade of Science class, sylabus, and lesson plan. The researcher also used the minimal grade of studying Hydrolysis subject in the eleventh grade of the Science class of SMA $\mathrm{N}$ Karangpandan in the academic year 2016/2017 in the 1st and 2nd cycle, the result of the affective assesment cycle in the 1st and 2 nd cycle and the result of the analysis ability assesment in the 1 st and 2 nd cycle.

The researcher using test and non test for the technique of collecting data in the 1 st and 2nd cycle. In this research,the instruments of the learning that had been used, are sylabus, lesson plan and hierarchy concept media although the instrument of the assesment was formed into 


\section{Jurnal Inovasi Pendidikan IPA, 3 (2), 2017 - 175}

Leny Yuliatun, Mohammad Masykuri, Budi Utami

cognitive test, affective questionnaire and analysis ability test.

\section{The Technique of Data Analysis}

The data of the research's result has been cultivated and analyzed in descriptive-qualitative by giving clearer illustrations about the process that related to the learning and ability analysis. The achievement of students' study was formed into cognitive and affective aspects.

The data of the research was analysed by using the analysis technique of Miles and Huberman that included data reduction, data presentation, conclusion taking and verification (Sugiyono, 2013 ).

Data reduction is a process of choosing and simplifying the result of the research data in the field. Data reduction has a function to give clearer illustration and make the researcher easier to do the next step of the research.

The presentation of the data is formed into diagram, table and short essay which gives simplicity for the researcher to understand the event and activity that happening in the action process and plan the next step that must be taken. The inspection of data validity is using data Triangulation technique which is the technique of collecting data to check the realibility of the data by interview, observation, document review, questionnaire and test. This techniques used can support the validity of his legitimate and data that have been taken so that in this study data obtained are reliable and are used as a result of the formulation of the problem.

\section{RESULT AND DISCUSSION}

Based on pre-cycle observation and interview, the researcher concludes that it is necessary to fix the learning to increase the analysis ability and study achievement of eleventh grade students of Science class of SMA $\mathrm{N} 1$ Karangpandan by concerning the character of students in the class.

One of the ways to fix the learning is by applying the discovery learning method by hierarchy concept on the Hydrolysis subject which is difficult and it needs an improvement to understand the material of the subject better.

\section{1st Cycle}

\section{Action Planning}

Action planning begun by the arrangement of lesson plan, sylabus and concept hierarchy media, observation sheet, question- naire and test. Lesson plan is made based on the style of the learning that used by the school. Sylabus is arranged focused on the sylabus that is used by the Chemistry teacher in the school. And the last is, all the instruments validated by two masters.

\section{Action on Doing}

Action on doing was done in 8 hours in the learning process. The 6 hours was done for the learning that used Discovery learning and 2 hours for evaluating the result of the action by doing an analysis abiliy test, refilling affective questionnaire and Hydrolysis cognitive test. Discovery Learning method has 6 syntaxs, those are problem statement stimulation, data collection, data management, verification and conclusion taking.

In the first meeting, the first cycle begun by giving stimulus which is salt, that is used in the daily activity then connecting it to the material of Hydrolysis. Then, teacher asked a question by writing alkali and acid reaction and also the salt that has been dissolved in the water. The students actively answered the questions of the teacher. The teacher chose one of the students to answer the questions. This beginning process has a function to get students' attention and inflict curiosity from the students before the class begun. After that, teacher explained the aim and the kind of learning method that would be used, that is Discovery Learning. Teacher explained the material that would be taught in the whole way in this meeting. The main activity begun by dividing group which consists of 5 people to work together, then teacher divided the discussion paper and emptied hierarchy concept that can be used by the students to be fulfilled.

From this case, researcher hoped students could ask and state orientations from the teacher so it can stimulate students to explore and state problems. Then, students did the questions and concept hierarchy to control data and collect data in the elaboration level. In the confirmation level, to make a clarification, both teacher and students correct the answer, teacher also asks the student to come before class to explain the answer. Next, teacher corrects the answer and act as a facilitator. In the closing, teacher together with students made a conclusion about the lesson in this meeting. Researcher also gave post-test to be a meeting reflection and explains sub-material for the next meeting. 
The process of learning in the 2 nd and 3rd meeting was same with the learning in the 1 st meeting. In the 3rd meeting, teacher closed the learning by giving a reminder about the next meeting that will be used to evaluate from the affective, cognitive, and analysis ability aspect.

Action Observation

Action observation was done by observing every process and event that happened in the learning. In the 1st cycle, 1st, 2nd and 3rd meeting, we can see that the enthusiasm of students to follow the learning by the exist method and media. Students are active to discuss and start bravely giving an opinion and asking if there is an obstacle when answering the questions. Beside doing an observation to know every event that happened, observation was done by doing a test. The result of analysis ability test presentated in the Table 3 .

Table.3. Result of the Assesment of Analysis Ability Aspect1 st Cycle

\begin{tabular}{cc}
\hline AnalysisAbility & Number of Students (\%) \\
\hline Very High & 2,5 \\
High & 50 \\
Normal & 40 \\
Low & 7,5 \\
Very Low & 0 \\
\hline
\end{tabular}

Based on the Table 3, we can say that the percentase of the anaysis ability in the high and very high category has not come to the target yet. The target of the analysis ability is $65 \%$ eventhough the result of analysis ability assesment aspect in the high and very high category on the 1 st cycle is just only $52,5 \%$. Based on the result above, it needs a follow-up action for the 2 nd cycle to make the analysis ability of the students can get the determined target.

Based on the cognitive test, there are 23 students who can get the target of the minimun grade salt Hydrolysis with percentage 57,5\% of the 40 students in the eleventh grade of Science class 1 . It makes the target of the cognitive completion in the 1st cycle hasn't get the target yet. The result of the cognitive aspect achievement in the Hydrolysis subject in the 2nd grade of Science class 1 in the 1 st cycle can be seen in the Figure 1.

Based on the result of the affective analysis aspect of the students, which is very good by the percentag $52,5 \%$, good by percentage $37,5 \%$, less better $10 \%$ and very low is $0 \%$. We can conclude that students can complete this aspect by the percentage $90 \%$ and for the 2 nd cycle, the assesment of affective aspect is used to see whether the attitude percentage gets the improvement or not after having the 2 nd cycle. The result of students' affective aspect achievement in the 1st cycle can be seen in the Figure 2.

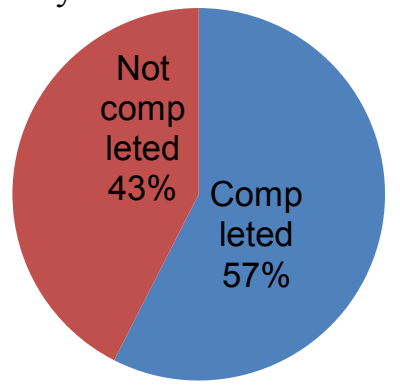

Figure 1. In the Pie Diagram of Completion Cognitive Apsect Study in the 1st Cycle.

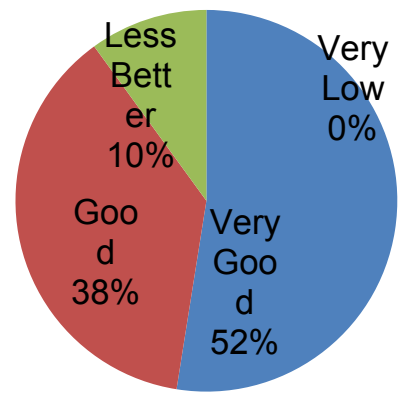

Figure 2. Pie Diagram of Affective Aspect Assesment in the 1st Cycle

Based on the result above, so the aspect of analysis ability and students' cognitive haven't got the determined target yet. Beside that, there is still a component on the analysis ability and the indicator of cognitive aspec that hasn't be achieved by the students. It needs a follow-up to cover up these problems, so the target can be achieved.

\section{Action Reflection}

Based on the result of the action observation, cognitive aspect and analysis abiliy hasn't got the determined target yet. So it needs a follow-up action in the 2 nd cycle. In the 2 nd cycle focused on the indicator and component that hasn't been masterd yet by the students. The planning of 2nd cycle begun by making a lesson plan which emphasized the indicator that hasn't been achieved by students in the 1st cycle on aspect of analysis ability and students' cognitive. The remedial learning in the 2 nd cycle hoped to reach the target that has been determined. 


\section{Jurnal Inovasi Pendidikan IPA, 3 (2), 2017 - 177}

Leny Yuliatun, Mohammad Masykuri, Budi Utami

\section{2nd Cycle}

\section{Action Planning}

The action planning in the 2nd cycle begun by making a lesoon plan from the researcher and subject teacher. In the 2nd cycle, the learning emphasized on the indicator which can't be achieved yet by the students. The discussion group in the 2nd cycle focused on the students' rate and the number of students in each group which makes it more less than before. Beside that, teacher also is also intensive in giving a lecture to every group to find out obstacles and difficulties of the students' discussion when studying about Hydrolysis material. So by that, students hoped to reach the determined target in this 2 nd cycle.

\section{Action on Doing}

The implementation of the learning in this 2nd cycle is 2 hours for the material focus and 1 hour for evaluation the learning process in the 2nd cycle is not different with the previous cycle. The difference in this stage, teacher as a faciliattor, is more intensive and gives questions to the students about the example of strong acid, strong alkali, weak acid and weak alkali to make students understand more about the characteristic of salt that formed from the reaction of acid and alkali. The evaluation of 2 nd cycle is the cognitive aspect consists of 4 multiple choices. For analysis ability aspect, the researcher gives 4 questions that hasn't been completed before. In the affective aspect, the researcher still measures it in the 1st cycle to find out the improvement of students' attitude after the action in the 2nd cycle.

\section{Action Observation}

In the learning of this 2nd cycle, students were still enthusiastic to follow the lecture. Students were more brave by the intensive lecture of the teacher, by this action, students were brave to give their opinion and ask the material that hasn't understood yet by them. In this 2nd cycle, students understood the Hydrolysis subject better. It was proved by the activity of the students who could cooperate well in the discussion group. They could explain the material that is still hard to be understood by other students. The result of the cognitive aspect of 2nd cycle can be seen in Figure 3.

The Figure 3 showed that thelearning in the 2 nd cycle has completed the determined target and the indicators of the learning has been achieved.

The result of the assesment of 2 nd analysis ability can be seen in the Table 4

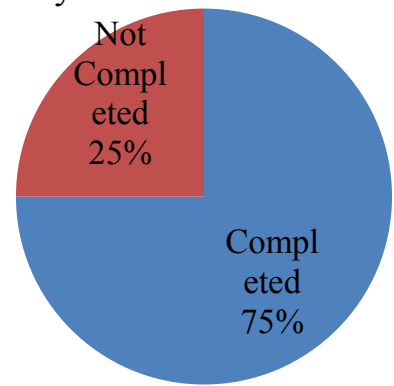

Figure 3. Pie Diagram of Cognitive Aspect of 2nd cycle

Table 4. Result of the Assesment of Analysis Aspect of 2nd Cycle

\begin{tabular}{ccc}
\hline Analysis Ability & $\begin{array}{c}\text { Number } \\
\text { of Students }\end{array}$ & $\begin{array}{c}\text { Percentage } \\
\text { (\%) }\end{array}$ \\
\hline Very High & 2 & 5 \\
High & 24 & 60 \\
Normal & 12 & 30 \\
Low & 2 & 5 \\
Very Low & 0 & 0 \\
\hline
\end{tabular}

Based on the Table 4, we can see that the percentage of analysis ability got a high and very high category. It reachs $65 \%$. So it has completed the determined target.

Beside that, in the affective aspect, there is an improvement of the students' percentage. It takes $2,5 \%$ of good and very good category in this cycle. This result showed that students have a better attitude after the remedial in the 2 nd cycle.

\section{Action Reflection}

Based on the data and the result of the action that has done, so the researcher can conclude that all the aspects including cognitive, affective, and analysis ability have reached the determined target and got the improvement from the 1st cycle till the 2 nd cycle. So by this result, the research has been stopped in the 2 nd cycle.

\section{The Comparison Action per Cycle}

The improvement result action of 1 st till 2nd cycle can be seen in the picture no. 4The improvement of the action showed taht the research has been succesfully done. It showed from the quality process which formed analysis ability and quality result of analysis ability and affective that can reach the determined target.

Quantitative data obtained in cognitive and affective aspects of processed and classified 
so that it can be to get a conclusion. This research showed that the concept of Hierarchy with the help and support discovery learning model, students' misconceptions can be resolved so that the analysis capability and achievements students increased reach the specified target.

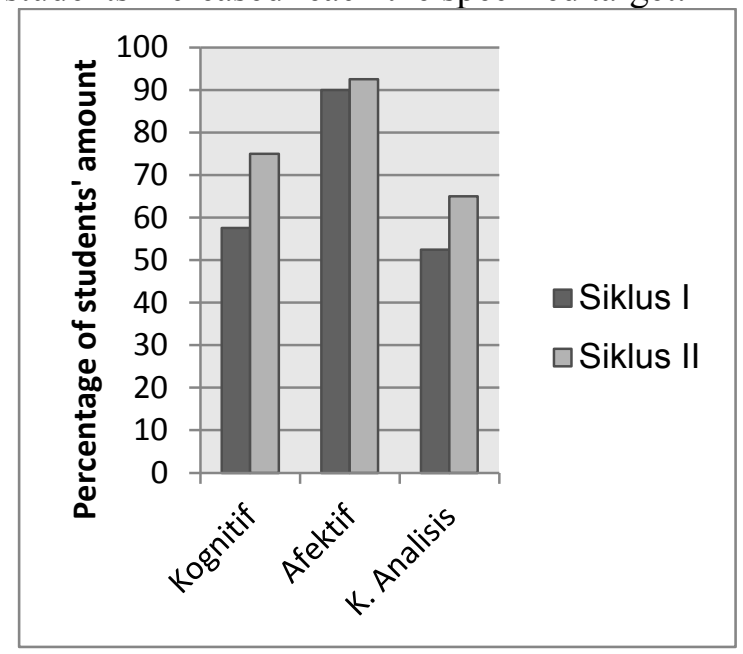

Figure 4. The Comparison of the Result Action per Cycle

Figure 4 showed the improvement of cognitive aspect, affective and analysis ability from 1 st cycle till 2nd cycle. So, we can conclude that Discovery Learning ( DL ) by the support of hierarchy concept can increase the chemistry study achievement on the Hydrolysis in the eleventh grade of Science class of SMA NKarangpandan in the academic year 2016/ 2017. This research has the same result with the research from Kadri and Rahmawati (2015, p. 33) stated that the result of hypothesis trial showed that Discovery Learning gives a significance influence than any conventional method in increasing the result of students' study. Beside that, it is also supported by the research from Istiana, Saputro \& Sukardjo (2015, p.72 ) said that the implementation of Discovery Learning can increase the activity of studyying and studying's achievement.

\section{CONCLUSION}

Based on the research that has been done, the researcher gets the result that the implementation of Discovery Learning method by the support of hierarchy concept can increase the analysis ability and students' studying achievement through salt Hydrolysis material in the eleventh grade of Science class of SMA N Karangpandan in the academic year 2016/2017. The analysis ability got increased from the 1st cycle, which is $52,5 \%$, to be $65 \%$ in the 2 nd cycle. The cognitive aspect from $57,5 \%$ in the 1 st cycle to be $75 \%$ in the 2 nd cycle. The affective aspect achievement in the 1st cycle is $90 \%$, it increases till $92,5 \%$ in the 2 nd cycle. All the indicators of every aspect has been achieved, it goes same with the determined target. This is in accordance with the research of Ratih, Ashari, and Arif (2015) that discovery learning model is effective to improve analytical ability of Class XI SMA Negeri 3 Purworejo in academic year 2014/2015.

\section{ACKNOWLEDGEMENTS}

The researcher wants to say fully thank you to Drs. Sumarno as the headmaster of SMA NKarangpandan who have given the permission to do a research. The researcher also wants to say thank you for Mr. Pranowo Sumarso, S.Pd who have given the permission to do a research in the class as the subject of this research.

\section{REFFERENCES}

Abdelrahman, P., \& Abdelrahman, K. (2014). The effect of using discovery learning strategy in teaching grammatical rules to first year general secondary student on developing their achievement and metacognitive skills, 5(2), 146-153.

Baharuddin \& Wahyuni, E.N. (2010). Teori belajar \& pembelajaran. Yogyakarta: Arruzz Media.

Barke, H.D, Hazari, A, \& Yitbarek, Sileshi. (2009). Misconceptions in chemistry. Berlin: Springer.

Dabbagh, N., \& Kitsantas, A. (2012). Internet and higher education personal learning environments, social media, and selfregulated learning: A natural formula for connecting formal and informal learning. The Internet and Higher Education, 15(1), 3-8. https://doi.org/10.1016/j.iheduc.2011.06.0 02

Facione, P. A. (2013). Critical thinking: What it is and why it counts. California: Reasons and The California Academic Press, Millbrae, CA.

Istiana, G.A, Saputro, A.N.C \& Sukardjo, J.S. (2015). Penerapan Model pembelajaran discovery learning untuk meningkatkan aktivitas dan prestasi belajar pokok bahasan larutan penyangga pada kelas XI IPA semester II SMA N 1 Ngemplak 


\section{Jurnal Inovasi Pendidikan IPA, 3 (2), 2017 - 179}

Leny Yuliatun, Mohammad Masykuri, Budi Utami

tahun pelajaran 2013/2014. Jurnal Pendidikan Kimia, 4 (2), 65-73.

Kadri, M \& Rahmawati, M. (2015).Pengaruh model pembelajaran discovery learning terhadap hasil belajar siswa pada materi pokok suhu dan kalor.Jurnal Ikatan Alumni Fisika Universitas Negeri Medan, 1 (1), 29-33.

Mustafa, \& Murset. (2013). Concept Maps as a tool for meaningful learning and teaching in chemistry education, $O$ (October), 152164.

Novak J.D \& Gowin, D.B. (2008).Learning how to learn. New York: Cambridge University Press.

Ratih, Ashari, Arif. (2015). Efektivitas Model pembelajaran discovery terbimbing dalam meningkatkan kemampuan berpikir analitis dan sikap ilmiah siswa Kelas XI SMA Negeri 3 Purworejo Tahun Pelajaran 2014/2015. Radiasi, 7(1), 1-4.

Sugiyono.(2013). Metode penelitian pendidikan. Bandung: Alfabeta.

Suprijono, A. (2014). Cooperative learning. Yogyakarta: Pustaka Pelajar.

Swaak, J, Jong, T.D \& Van Joolingen, W.R. (2004).The effect of discovery learning and expository instruction on the acquisition of definitional and intuitive knowledge.Journal of Computer Assisted Learning, 20, 225-234.

Winarti. (2015). Profil kemampuan berpikir analisis dan evaluasi mahasiswa dalam mengerjakan konsep kalor. Jurnal Inovasi Dan Pembelajaran Fisika, 2(1), 19-24. 